\title{
Nuances in the Philosophy of the Cosmonomic Idea
}

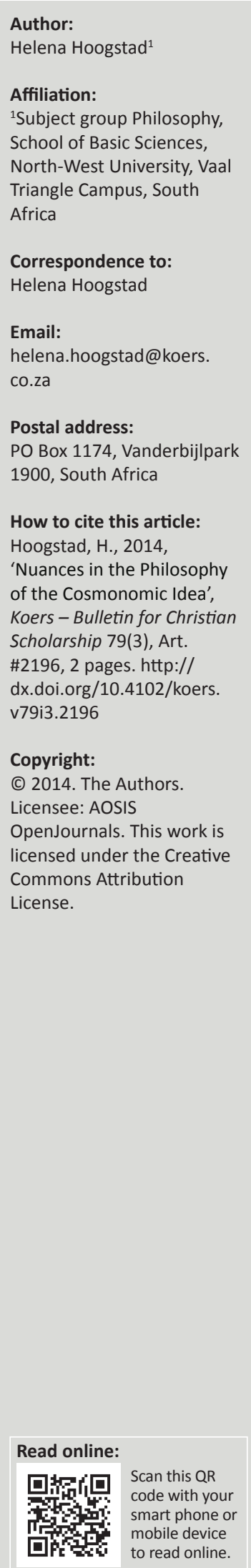

It is a great pleasure to present this special number entitled Nuances in the Philosophy of the Cosmonomic Idea to our Koers readers, the Reformational scholarly community and special science practitioners.

This issue is organised around a perceptive article of the same title in which Marinus Dirk Stafleu comments on Danie Strauss's Philosophy: Discipline of the disciplines (see Cameron 2009; Griffioen 2013; Strauss 2009). The latter's stimulating book, published in 2009, further develops and critically updates Herman Dooyeweerd's Philosophy of the Cosmonomic Idea (PCI). Stafleu's article highlights some differences between his own, Strauss's and Dooyeweerd's interpretation of the PCI and points to the importance of artefacts and technology in his own exploration of the reformational project.

Following a suggestion by Bruce Wearne, Koers invited scholars to respond to Stafleu's article. The replies by Andrew Basden, Maarten Verkerk and Danie Strauss are published here.

Basden, in his article Understanding artefacts related to human aspects: The case of information technology and systems, analyses Stafleu's discussion of artefacts that are differentiated by reference to the aspect onto which the technical activity is projected; unfortunately, Stafleu's discussion is restricted to the six pre-human aspects. In response, Basden considers information and communication technology as a kind of artefact directed at the lingual, a human aspect. He further outlines how Dooyeweerd's theory of modal aspects can be used in studying information technology and computer systems, while also mentioning how this study may inform Dooyeweerdian philosophy itself.

Verkerk's contribution as a philosopher-practitioner pays tribute to both Stafleu and Strauss and emphasizes the importance of the availability of Christian philosophical concepts in designing technology. In The dual challenge of Christian philosophy: How to make philosophical ideas and concepts available for engineers? he applies philosophy-based tools to engineering practice.

In the fourth and last article of this issue, Systematic considerations within the philosophy of the Cosmonomic Idea, Danie Strauss shows how many of the apparent differences between himself and Stafleu can be understood to be terminological differences. Strauss emphasises the value of Stafleu's elaboration of particular human skills characterised by different modal aspects.

This issue of Koers not only offers Stafleu's many thoughtful insights as it provokes further refined scholarly work, but also intends to honour his significant long-term contribution (refer to Appendix 1) to Christian reflection in both the special sciences and philosophy.

\section{References}

Cameron, A., 2012, 'Book review of: Philosophical frameworks for understanding information systems', Philosophia Reformata 77, 85-90. Griffioen, S., 2012, 'Danie Strauss: Philosophy as discipline of disciplines', Koers - Bulletin for Christian Scholarship 77(2), Art. \#409, 3 pages. http://dx.doi.org/10.4102/koers.v77i2.409

Strauss, D.F.M., 2009, Philosophy: Disciplines of the disciplines, Padeia Press, Grand Rapids. 


\section{Appendix 1}

\section{Philosophical publications by Marinus Dirk Stafleu}

1966, 'Quantumfysica en wijsbegeerte der wetsidee', Philosophia Reformata 31, 126-156.

1968, 'Individualiteit in de fysica', in D.M Bakker et al., Reflexies, opstellen aangeboden aan Prof. Dr. J.P.A. Mekkes, ter gelegenheid van zijn zeventigste verjaardag, pp. 287-305 Amsterdam: Buijten en Schipperheijn.

1970, 'Analysis of time in modern physics', Philosophia Reformata 35, 1-24; 119-131.

1972, 'Metric and measurement in physics', Philosophia Reformata 37, 42-57.

1978 , 'The mathematical and technical opening up of a field of science', Philosophia Reformata 43, 18-37.

1979, 'The isolation of a field of science', Philosophia Reformata 44, 1-15.

1980, 'The opening up of a field of science by abstraction and synthesis', Philosophia Reformata 45, 47-76.

1980 , Time and again, A systematic analysis of the foundations of physics, Wedge/Sacum, Bloemfontein/ Toronto.

1981-1982, 'Theories as logically qualified artefacts', Philosophia Reformata 46, 164-189; 47, 20-40.

1983-1984, 'Kritische studie: Popper's Postscript', Philosophia Reformata 48, 50-65; 49, 71-91.

1984, 'The kind of motion we call heat', Tydskrif vir christelike wetenskap 20, 1-43.

1985, 'Spatial things and kinematic events (On the reality of mathematically qualified structures of individuality)', Philosophia Reformata 50, 9-20.

1986, 'Some problems of time - some facts of life', Philosophia Reformata 51, 67-82.

1987, Theories at work, On the structure and functioning of theories in science, in particular during the Copernican revolution, Lanham, University Press of America, New York/London.

1988, 'Criteria for a law sphere (with special emphasis on the 'psychic' modal aspect)', Philosophia Reformata 53, 171-186.

1989, De verborgen structuur, Wijsgerige beschouwingen over natuurlijke structuren en hun samenhang, Buijten en Schipperheijn, Amsterdam. 1991, 'Being human in the cosmos', Philosophia Reformata 56, 101-131.

1992, En toch beweegt zij, Geschiedenis van de natuurkunde van Pythagoras tot Newton, Boom, Meppel etc.

1994, 'De structuur der materie in de wijsbegeerte van de wetsidee', in H.G. Geertsema et al. (eds.), Herman Dooyeweerd 1894-1977, Breedte en actualiteit van zijn filosofie, pp. 114-142, Kok, Kampen.

1995, 'The cosmochronological idea in natural science', in S. Griffioen, B.M. Balk (eds.), Christian philosophy at the close of the twentieth century, pp. 93-111, Kok, Kampen.

1995, 'Modelvorming als heuristisch instrument in het wetenschappelijke ontsluitingsproces', Philosophia Reformata 60, 1-15.

1996, 'Filosofie van de natuurwetenschap', in R. van Woudenberg (red.), Kennis en werkelijkheid, pp. 177-202, Buijten en Schipperheijn, Amsterdam.

1997, 'Comments on anticipations', Philosophia Reformata 62, 129-144.

1998, Experimentele filosofie, Geschiedenis van de natuurkunde vanuit een wijsgerig perspectief, Buijten en Schipperheijn, Amsterdam.

1999, 'The idea of natural law', Philosophia Reformata 64, 88-104.

2000, 'The idionomy of natural kinds and the biological concept of a species', Philosophia Reformata 65, 154-169.

2002, Een wereld vol relaties, Karakter en zin van natuurlijke dingen en processen, Buijten en Schipperheijn, Amsterdam. (translation: Stafleu 2006, part IV; Stafleu 2010).

2002, 'Evolution, history and the individual character of a person', Philosophia Reformata 67, 3-18.

2003, 'On aesthetically qualified characters and their mutual interlacements', Philosophia Reformata 68, 137-147.

2004, 'On the character of social communities, the state and the public domain', Philosophia Reformata 69, $125-139$.

2005, 'The relation frame of keeping company. Reply to Andrew Basden', Philosophia Reformata 70, 151-164.

2006, 'Infinity and continuity', Tydskrif vir Christelike Wetenskap, 163-174.

2006, Relations and characters in Protestant philosophy, from http://www.freewebs.com/stafleu

2007, 'Philosophical ethics and the so-called ethical aspect', Philosophia Reformata 72, 21-33.

2008, 'Isaac Newtons Philosophiae naturalis principia mathematica', Radix 34, 39-53.

2008, 'Time and history in the Philosophy of the Cosmonomic Idea', Philosophia Reformata 73, 154-169.

2010, A world full of relations, from http://www.scibd.com/doc/29057727 (pdf, translation of Stafleu 2002a).

2011, 'Bestaan driehoeken en cirkels echt?', Sophie 1(4), 44-47.

2011, Chronos \& Clio, De tijd in de geschiedenis, Buijten en Schipperheijn, Amsterdam.

2014, 'Nuances in the Philosophy of the Cosmonomic Idea', Koers - Bulletin for Christian Scholarship 79(3), Art. \#423, 8 pages. http://dx.doi. org/10.4102/koers.v79i3.423

2015, Acts, artefacts, and associations, A Christian social philosophy of ethics, history, and policy, to be published.

2015, Theory and experiment, Christian philosophy of science in a historical context, to be published. 